\title{
Uji Daya Hambat Anti Bakteri Air Perasan Daging Buah Nanas (Ananas Comosus (L) Merr Var. Queen) terhadap Bakteri Eschericia Coli
}

\author{
Pieter Julius. Daely ${ }^{1}$, Sarwendah $^{2}$, Yusliana ${ }^{3}$, Heronimus C. G. Laia ${ }^{4}$, Suhartina Damardi ${ }^{5}$ \\ 1,2,3,4,5 Fakultas Kedokteran Universitas Prima Indonesia, Medan \\ Email: pieterdaely.07@gmail.com
}

\begin{abstract}
Pineapple fruit (Ananas comosus (L) Merr) is one type of tropical fruit that is consumed by many people. Pineapple is also commonly used by the community as an antibacterial, anti-inflammatory, anti-coagulant, and anti-cancer. The purpose of this study was to determine the effectiveness of the antibacterial inhibitory effect of pineapple juice (Ananas comosus ( $L$ ) Merr Var. Queen) on Eschericia coli bacteria. This study used an experimental laboratory method with disc diffusion and using ciprofloxacin disc as a positive control and distilled water as a negative control. Based on the results of research that has been done, it can be concluded that pineapple juice (Ananas comosus (L) Merr Var. Queen) at a concentration of 25\%, 50\%, 75\%, and 100\% has the effectiveness as an antibacterial in inhibiting the growth of Eschericia coli bacteria.
\end{abstract}

Keywords : inhibitory power, pineapple fruit, bacteria.

\section{PENDAHULUAN}

Penyakit infeksi dinyatakan masih merupakan penyebab utama tingginya angka kesakitan (morbidity) dan angka kematian (mortality) di seluruh dunia termasuk Indonesia. Infeksi dapat disebabkan oleh berbagai mikroorganisme seperti bakteri, virus, jamur, dan parasit (Radji, 2018).

Salah satu pengobatan klinis untuk menangani penyakit infeksi adalah penggunaan antibiotik. Namun, penggunaan antibiotik diketahui menyebabkan masalah baru yaitu munculnya resistensi terutama pada pemakaian antibiotik yang tidak prosedural dan tidak terkontrol, sehingga pengobatan penyakit menular menjadi tidak efektif. Resistensi antibiotik adalah salah satu ancaman utama terhadap pengobatan modern, sehingga membutuhkan strategi baru dalam membangun alternatif dalam kasus infeksi (Erviani, 2013).

Obat herbal telah diterima secara luas di hampir seluruh negara di dunia. Menurut WHO (2016), negaranegara di Afrika, Asia dan Amerika Latin menggunakan obat herbal sebagai pelengkap pengobatan primer. Bahkan di Afrika, sebanyak $80 \%$ dari populasi menggunakan obat herbal untuk pengobatan primer. Faktor pendorong terjadinya peningkatan penggunaan obat herbal di negara maju adalah usia harapan hidup yang lebih panjang pada saat prevalensi penyakit kronik meningkat, adanya kegagalan penggunaan obat modern untuk penyakit tertentu di antaranya kanker serta semakin luas akses informasi mengenai obat herbal di seluruh dunia. WHO merekomendasi penggunaan obat tradisional dalam pemeliharaan kesehatan masyarakat, pencegahan dan pengobatan penyakit, terutama untuk penyakit kronis, penyakit degeneratif dan kanker (Bustanusalam, 2016).

Penggunaan obat tradisional secara umum dinilai lebih aman dari pada penggunaan obat modern. Hal ini disebabkan karena obat tradisional memiliki efek samping yang relatif lebih sedikit. Bangsa Indonesia telah lama mengenal dan menggunakan tanaman berkhasiat obat sebagai salah satu upaya dalam menanggulangi masalah kesehatan. Pengetahuan tentang tanaman berkhasiat obat berdasarkan pada pengalaman dan ketrampilan yang secara turun temurun telah diwariskan dari satu generasi ke generasi berikutnya dikenal sebagai jamu (Jumiarni, 2017).

Tanaman obat adalah tanaman yang bermanfaat untuk obat-obatan dan kesehatan yang di konsumsi atau digunakan dari bagian-bagian tanaman seperti buah, batang, daun, umbi (rimpang) ataupun akar (Lestaridewi, 2017).

Buah nanas (Ananas comosus (L) Merr) merupakan salah satu jenis buah-buahan tropis yang banyak diminati masyarakat lokal dan internasional. Selain rasanya yang manis, buah ini mempunyai banyak manfaat bagi kesehatan tubuh (Maisarah, 2014).

Nanas termasuk buah yang mempunyai kandungan sangat kompleks, kaya akan mineral baik makromaupun mikro, zat organik, air, vitamin dan kandungan senyawa lain seperti Klor, lodium, Fenol, Flavanoid dan Enzim Bromealin (Manarisong, 2015).

\section{METODE PENELITIAN}

Jenis Penelitian ini merupakan penelitian eksperimental laboratorium dengan menggunakan metode difusi cakram, untuk melihat pengaruh air perasaan daging buah nanas (Ananas comosus ( $L$ ) Merr Var Queen) terhadap pertumbuhan bakteri Salmonella typhi.Penelitian ini dilakukan pada Desember 2018 Januari 2019 di Laboratorium Mikrobiologi Fakultas Kedokteran Universitas Prima Indonesia. Sampel yang digunakan adalah buah nanas muda dengan umur 3 bulan yang dibeli dari pasar tradisional Perbaungan, Kabupaten Serdang Bedagai.

\section{Alat dan Bahan}

Alat yang digunakan dalam penelitian ini adalah juicer, pisau, tabung Erlenmeyer, bekker glass, tabung reaksi, rak tabung, cawan petri, pinset, lidi kapas, ose, kertas whatman, pipet tetes, autoklaf, oven, inkubator, api Bunsen, timbangan analitik, alumunium foil, jangka sorong, kamera, kertas stiker label, perforator, masker, sarung tangan. Bahan yang diperlukan dalam penelitian ini adalah buah nanas, sabun antiseptik (Dettol), bakteri Salmonella typhi, disc ciprofloxacin, aquades, Mueller Hinton Agar (MHA), dan Nutrient Broth (NB). 


\section{Pembuatan Muller Hinton Agar (MHA) Dan Media Nutrien Broth (NB)}

6,8 gram bahan media MHA dilarutkan dengan menggunakan aquadest sebanyak $200 \mathrm{ml}$ ke dalam tabung Erlemeyer, kemudian diletakkan diatas hotplate autoklaf dengan suhu $121^{\circ} \mathrm{C}$ selama 15 menit. Media MHA dituang ke dalam cawan petri sebanyak $25 \mathrm{ml}$.

Untuk membuat media cair (NB), ditimbang sebanyak 1 gram serbuk NB dan dimasukkan kedalam gelas piala $500 \mathrm{~mL}$, kemudian ditambahkan aquades sebanyak $150 \mathrm{~mL}$. Kemudian dipanaskan diatas hotplate sampai semua bahan larut dan homongen. Setelah itu, larutan dimasukakan kedalam tabung Erlenmeyer dan selanjutnya siap untuk di autoklaf pada suhu $121^{\circ} \mathrm{C}$ selama 45 menit. Kemudian media cair dimasukkan dalam tabung reaksi. Media yang telah di sterilkan tersebut disimpan dalam kulkas dan siap untuk digunakan (Saridewi NM, 2017).

\section{Sterilisasi Alat}

Juicer dicuci dengan air bersih dan buah nanas yang sudah dikupas kulitnya. Pisau, gelas beaker, labu ukur dan tabung reaksi dicuci dengan sabun cuci yang mengandung bahan antiseptik kemudian dikeringkan dan alat-alat yang terbuat dari gelas disterilkan dengan cara dimasukkan ke dalam oven pada suhu $170^{\circ} \mathrm{C}$ selama 1 jam. Media disterilkan dalam autoklaf pada suhu $121^{\circ} \mathrm{C}$ selama 15 menit. Ose dan pinset disterilkan dengan melakukan pemijaran di atas api Bunsen.

\section{Pembuatan Konsentrasi}

Buah nanas dipotong dan dipisahkan daging buah dari kulit dan bonggolnya menggunakan pisau. Daging buah nanas yang selanjutnya dimasukkan ke dalam juicer. Jus yang dihasilkan kemudian disaring dengan mengunakan corong gelas yang di alasi dengan kertas whatman kemudian ditampung menggunakan tabung erlenmeyer selanjutnya di pindahkan ke dalam gelas beaker untuk di lakukan pemekatan dengan menggunakan water bath selanjutnya ditutup dengan alumunium foil. Air perasan tersebut merupakan air perasan daging buah nanas dengan konsentrasi $100 \%$. Konsentrasi yang digunakan diperoleh dengan rumus :

$M 1 . V 1=M 2 . V 2$

Keterangan :

$\mathrm{M} 1=$ molaritas sebelum pengenceran

$\mathrm{M} 2=$ molaritas setelah pengenceran

$\mathrm{V} 1=$ volume sebelum pengenceran

$\mathrm{V} 2=$ volume setelah pengenceran

\section{Uji Efek Antibakteri}

Metode pengujian efek antibakteri yang digunakan dalam penelitian ini yaitu metode difusi cakram. Untuk pengujian ini digunakan media Mueller Hinton Agar (MHA) sebanyak dua cawan petri dan 10 buah cakram kertas whatman. Kertas whatman dibuat dengan perforator sehingga berbentuk cakram dengan diameter $6 \mathrm{~mm}$. Sebelum bakteri ditanam pada media Mueller Hinton Agar (MHA), bagian depan cawan petri dibagi menjadi empat dan diberi kode menggunakan kertas stiker label. Lidi kapas dicelupkan ke dalam suspensi bakteri pada media Nutrient Broth (NB) kemudian digoreskan pada media Mueller Hinton Agar (MHA).

Air perasan daging buah nanas yang ada di dalam labu ukur dikocok terlebih dahulu kemudian dituang ke dalam tabung reaksi. Pada masing-masing tabung reaksi konsentrasi air perasan daging buah nanas $(25 \%$, $50 \%, 75 \%, 100 \%)$ dicelupkan satu cakram kertas whatman, kontrol positif digunakan dua buah disc ciprofloxacin dan kontrol negatif digunakan dua cakram kertas whatman dicelupkan pada aquades. Setelah itu, kertas cakram diletakkan pada permukaan media Mueller Hinton Agar (MHA) dengan bantuan pinset steril dengan sedikit penekanan agar cakram kertas whatman melekat dengan baik, kemudian diinkubasi pada suhu $37^{\circ} \mathrm{C}$ selama 48 jam. Hitung zona hambat atau zona bening yang terbentuk pada cakram kertas whatman dengan menggunakan jangka sorong (Makalew, dkk., 2016).

Tabel 1. Kekuatan daya hambat antibakteri (Darvis dan Stout, 1997)

\begin{tabular}{cc}
\hline $\begin{array}{c}\text { Kriteria kekuatan } \\
\text { daya antibakteri }\end{array}$ & $\begin{array}{c}\text { Diameter zona } \\
\text { hambat }(\mathbf{m m})\end{array}$ \\
\hline Lemah & $<5$ \\
Sedang & $5-10$ \\
Kuat & $10-20$ \\
Sangat kuat & $>20$ \\
\hline
\end{tabular}

\section{HASIL DAN PEMBAHASAN}

Zona hambat yang terbentuk diukur diameter vertikal dan diameter horizontal pada permukaan media dengan menggunakan jangka sorong dalam satuan milimeter (mm). Pengukuran dilakukan sebanyak 10 kali, yaitu dua kali pada tiap kelompok perlakuan kontrol. Hasil penelitian dengan menggunakan konsentrasi 25\%, $50 \%, 75 \%$ dan $100 \%$ didapatkan zona hambat seperti yang tercantum dalam tabel,grafik, dan gambar.

Tabel 2. Hasil Diameter Zona Hambat Air Perasan Daging Buah Nanas Terhadap Pertumbuhan Bakteri Eschericia coli.

\begin{tabular}{clccc}
\hline Bakteri & Perlakuan & \multicolumn{2}{c}{ Diameter Zona Hambat (mm) } & Rata-rata \\
& & Pengulangan1 & Pengulangan 2 & $(\mathrm{mm})$ \\
\hline & Konsentrasi 25\% & $8,12 \mathrm{~mm}$ & $10 \mathrm{~mm}$ & 9,06 \\
& Konsentrasi 50\% & $8,4 \mathrm{~mm}$ & $11,6 \mathrm{~mm}$ & 10 \\
\multirow{3}{*}{ Escherichia coli } & Konsentrasi 75\% & $8,68 \mathrm{~mm}$ & $12,3 \mathrm{~mm}$ & 10,49 \\
& Konsentrasi 100\% & $8,80 \mathrm{~mm}$ & $13,2 \mathrm{~mm}$ & 11 \\
& Kontrol positif & $20,8 \mathrm{~mm}$ & $24,3 \mathrm{~mm}$ & 22,55 \\
& Kontrol negatif & - & - & - \\
\hline
\end{tabular}




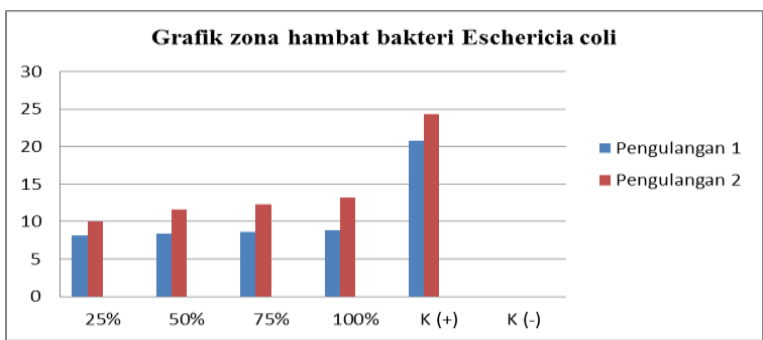

Grafik 1. Hasil pengukuran zona hambat air perasan daging buah nanas terhadap bakteri E.coli.

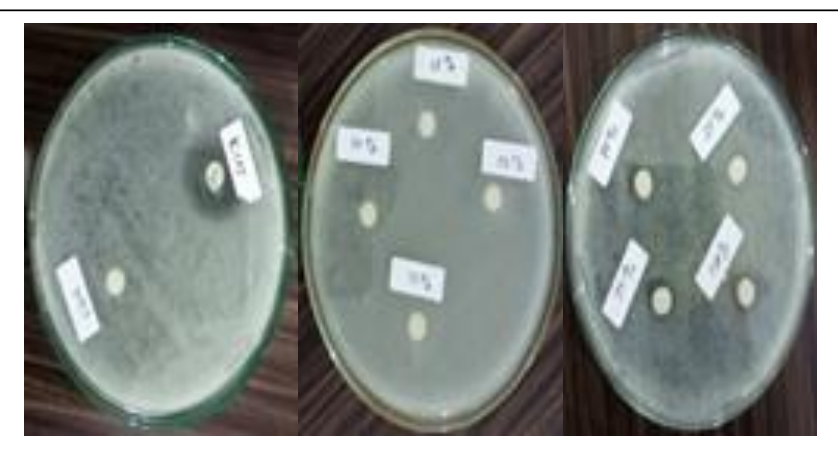

Gambar 2. Zona Hambat Air Perasan Daging Buah Nanas Terhadap Bakteri Eschericia coli.

\section{Pembahasan}

Berdasarkan tabel 1 dan grafik 1 . Didapatkan bahwa hasil zona hambat dari tiap konsentrasi berbeda dengan rata-rata diameter zona hambat pada konsentrasi $25 \%$ sebesar $9,06 \mathrm{~mm}, 50 \%$ sebesar 10 $\mathrm{mm}, 75 \%$ sebesr $10,49 \mathrm{~mm}$ dan $100 \%$ sebesar $11 \mathrm{~mm}$.

Berdasarkan gambar 1. Hasil pengamatan yang dilakukan pada cawan petri yang berisi kontrol positif memiliki efektifitas sangat kuat sebagai antibiotik dan pada kontrol negatif tidak menunjukkan efektifitas sedangkan pada air perasan daging buah nanas (Ananas comosus(L) Merr Var. Queen) yang dilakukan pengenceran dengan konsentrasi 25\%, 50\%, 75\% memiliki efektivitas sedang sebagai antibakteri dan pada kosentrasi $100 \%$ memiliki efektivitas kuat sebagai antibakteri dalam menghambat pertumbuhan bakteri Eschericia coli.

\section{SIMPULAN}

Hasil penelitian yang telah dilakukan menunjukkan bahwa air perasan daging buah nanas (Ananas comosus (L) Merr Var. Queen) pada konsentrasi $25 \%$, 50\%, 70\%, dan $100 \%$ memiliki efektivitas sebagai antibakteri dalam menghambat pertumbuhan bakteri Eschericia coli.

\section{DAFTAR PUSTAKA}

Ahamed, AA. Etc. 2016. Evaluation of Antimicrobial Activity of Pineapple Extrac Against Selected Microbes. International Journal of Pharma and Biosciences. no. 55. Page 277-278, 2016.

Bustanusalam. Pemanfaatan Obat Tradisional (Herbal) Sebagai Obat Alternatif. BioTrends. vol.7, no.1 pp 20-25, 2016

Davis dan Stout. Dics Plate Method Of Microbiologi Antibiotic Eassay. J. Of Microbiologi. 22:4-9,1997.
Erviani EA. Analisis Multidrug Resisten Antibiotik Pada Salmonella typhi Dengan Teknik Multiplex PCR. J. IImiah Biologi.vol 1, no. 1, pp 51-60, 2013.

Jumiarni WO, Komalasari O. Jenis Dan Pemanfaatan Tumbuhan Obat Pada Masyarakat Suku Muna Di Permukiman Kota Wuna.Trad. Med. J.vol. 22(1), p 45-56,2017.

Lestaridewi KN, Jamhari $M$, Isnainar. Pemanfaatan Aman Sebagai Obat Tradisional Di Desa Tolai Kecamatan Torue Kabupaten Parigi Moutong.eJIPBIOL.vol.5(2):92-108, 2017.

Maisarah. Panduan Paraktis Budaya Nanas. Edisi 1. Yogyakarta: Penerbit Indopublika; 2014.

Makalew MAJ, Nangoy E, Wowor PM. Uji Antibakteri Air Perasaan Daging Buah Nanas (Ananas comosus (L) Merr) Terhadap Bakteri Klebsiella Pneumoniae. J. e-Biomedik. 2016.

Manarisong A, Abidjulu J, Siagian VS. Uji Daya Hambat Ekstrak Kulit Nanas (Ananas comosus L) Terhadap Bakteri Staphylococus aureus Secara In Vitro.J. IImiah Farmasi - UNSRAT. vol. 4 no. 4, pp 27-23, 2015.

Radji M. Mikrobiologi Panduan Mahasiswa Farmasi dan Kedokteran. Jakarta. Penerbit Buku Kedokteran EGC; 2018.

Saridewi NM, Meiskha B, Anisa. Uji Efektivitas Antibakteri Perasan Jus Buah Nanas (Ananas comosus) Terhadap Pertumbuhan Isolat Bakteri Plak Gigi di Puskesmas Kecamatan Tanah Abang. J. Biogenesis.; vol.6(2): pp 104-110.2017. 